\title{
Efficiency of Various Formulations of Urea Coated with Bioaugmented (Bacillus sp.) ZnO to Improve Growth, Yield and Zn Contents of Wheat Grains
}

\author{
Qudsia Nazir', 2*, Azhar Hussain ${ }^{3 * *}$, Muhammad Zahid Mumtaz ${ }^{4}$, Abid Niaz ${ }^{1}$, \\ Muhammad Arif ${ }^{1}$, Muhammad Aftab ${ }^{1}$, Ana Aslam1, Tariq Aziz ${ }^{2}$ \\ ${ }^{1}$ Soil Chemistry Section, Ayub Agricultural Research Institute, Faisalabad, 38000 Pakistan \\ ${ }^{2}$ Institute of Soil and Environmental Sciences, University of Agriculture, Faisalabad, 38040 Pakistan \\ ${ }^{3}$ Department of Soil Science, The Islamia University of Bahawalpur, 63100 Pakistan \\ ${ }^{4}$ Institute of Molecular Biology and Biotechnology, The University of Lahore, Main Campus, \\ Defense Road Lahore, 54000 Pakistan
}

Received: 8 April 2020

Accepted: 3 June 2020

\begin{abstract}
Zinc $(\mathrm{Zn})$ biofortification in staple cereal grains is a low-cost and viable option to overcome the $\mathrm{Zn}$ deficiency in humans beings in developing countries. Intensive cropping with no/low micronutrient fertilization has resulted in soil Zn deficiency around the globe. Moreover, the Zn use efficiency of soils is usually low owing to its fixation into unavailable forms. Hence, the present study was conducted to investigate the integrated effects of urea coated with bioaugmented $\mathrm{Zn}$ on wheat growth, yield, and $\mathrm{Zn}$ biofortification. The bioaugmented $\mathrm{Zn}$ was prepared by inoculating $\mathrm{ZnO}$ with Bacillus sp. AZ6. Three levels $(0.5,1.0$, and $1.5 \%)$ of $\mathrm{ZnO}$, bioaugmented $\mathrm{Zn}$, and bioaugmented $\mathrm{Zn}+$ organic material were coated on urea fertilizer and applied to investigate the performance of the wheat crop. The applied treatments were compared with absolute control and sole application of $\mathrm{ZnSO}_{4}$, and Bacillus sp. AZ6. Results revealed that the application of urea coated with $1.5 \%$ bioaugmented $\mathrm{Zn}$ significantly increased wheat growth, yield, and $\mathrm{Zn}$ biofortification as compared to the sole $\mathrm{ZnSO}_{4}$, and Bacillus sp. AZ6 treatments. The application of urea coated with $1.5 \%$ bioaugmented $\mathrm{Zn}$ improved the accumulation of $\mathrm{Zn}$ in shoots and grains by $83.3 \%$ and $144.0 \%$, respectively, compared to absolute control. The increase in grain $\mathrm{Zn}$ content was owing to the significant reduction in grain phytic acid (69.9\%) and phytate: $\mathrm{Zn}$ molar ratios $(87.6 \%)$ compared to absolute control. Therefore, it was concluded that the application of urea coated with bioactivated $\mathrm{ZnO}$ can improve $\mathrm{Zn}$ biofortification in wheat grain by reducing phytic acid concentrations, consequently fulfilling human $\mathrm{Zn}$ needs through the consumption of such $\mathrm{Zn}$ enrich wheat grains.
\end{abstract}

Keywords: Anti-nutrients; Bacillus sp.; Biofortification; Phytic acid; Zinc-coated urea

\footnotetext{
*e-mail: sbqnazir@gmail.com

**e-mail: azharhaseen@gmail.com
} 


\section{Introduction}

Food security is a fundamental challenge of the $21^{\text {st }}$ century considering the ever-increasing population [1]. Malnutrition had been observed in 820 million people globally, suggesting the feeding of unhealthy diet, the global burden of diseases, overweight, and/or obesity [2]. Zinc (Zn) malnutrition had been observed in onethird of the world's population that causes a delay in growth, as well as various disorders including diarrhea, pneumonia, disturbed neuropsychological performance, and abnormalities of fetal development [3]. The $\mathrm{Zn}$ deficiency can be overcome by taking supplements or using diversified and fortified diets; however, this approach is inefficient owing to higher costs which in unaffordable for poor developing countries with a serious risk of food security. The majority of the people rely on cereals as their staple diet and cannot afford diversification in developing countries. As these cereals are generally grown on low $\mathrm{Zn}$ soils, hence are deficient in $\mathrm{Zn}$, ultimately causing its deficiency in humans [4]. The most economic and viable approach to improve $\mathrm{Zn}$ nutrition of low-income people is to increase $\mathrm{Zn}$ concentration in the edible portion of crops [5] and this can be achieved through biofortification $[4,6]$. $\mathrm{Zn}$ biofortification is being carried out through numerous ways such as genotype assortment and improvement achieved by using genetic engineering and conventional breeding methods [7]. However, the majority of these approaches are either inefficient or expensive.

Zinc fertilizer application in the soil is reported to increase $\mathrm{Zn}$ contents in grains [4, 8]; however, the $\mathrm{Zn}$ use efficiency of most of the soils is usually low, as the applied $\mathrm{Zn}$ tends to become insoluble in calcareous and high $\mathrm{pH}$ soils [9]. Furthermore, the majority of the farmers unaware of the nutritional value/quality of the produce, and therefore, do not apply appropriate $\mathrm{Zn}$ fertilizers. Hence, there is a dire need for time to improve $\mathrm{Zn}$ use efficiency and to motivate the farmers for $\mathrm{Zn}$ application in developing countries. Moreover, efficient and low-cost $\mathrm{Zn}$ fertilizers should be developed with higher $\mathrm{Zn}$ use efficiency. Thus, certain microorganisms have been identified to solubilize the unavailable forms of $\mathrm{Zn}$ in soil and may serve as the potential tool for improved $\mathrm{Zn}$ use efficiency. For instance, bioaugmentation of $\mathrm{Zn}$ solubilizing bacteria (ZSB) in plants has been reported to increase the bioavailability of $\mathrm{Zn}$ for plant uptake even in calcareous soils [10-12]. The ZSB could transform fixed Zn into a soluble form that has emerged as a novel sustainable and environment-friendly approach to improve soil $\mathrm{Zn}$ availability and biofortification. Bacillus spp. had been reported as the most dominating ZSB bacterial genera [11-14]. Such bacteria are capable of producing secondary metabolites, which acidify the soil medium and improve the bioavailability of nutrients to the plants. Studies demonstrated that a one-unit decrease in soil $\mathrm{pH}$ may increase $\mathrm{Zn}$ bioavailability a hundredtimes and vice versa [15]. The application of such potential bioinoculant may improve plant growth through improving the bioavailability of nutrients and their accumulation to biofortified the grains [11, 13]. However, organic and biofertilizers have not gained much attention from the farmers, owing to the lack of awareness, difficulty in application methods, inconsistent crop responses, and higher costs. Hence, there is dire need to develop such integrated fertilizer formulations or application methods aiming at not only increased fertilizer use efficiency but also to improve soil health and crop yields.

Generally, urea is being used as mineral fertilizer with no to low use of $\mathrm{P}, \mathrm{K}$, and micronutrients by the farmers. Therefore, the present project was conducted to develop a $\mathrm{ZnO}$ coated urea augmented with ZSB (Bacillus sp. AZ6) with the hypothesis that this fertilizer will not only improve $\mathrm{Zn}$ use efficiency but will also improve the $\mathrm{Zn}$ biofortification ( $\mathrm{Zn}$ contents in grains) of wheat. Further, the application of this integrated fertilizer would be easier and save the labor costs for the application of $\mathrm{Zn}$ and biofertilizers individually. Moreover, the $\mathrm{ZnO}$ source of $\mathrm{Zn}$ is cheaper than conventional $\mathrm{ZnSO}_{4}$ fertilizer, thus will reduce the cost of $\mathrm{Zn}$ fertilizer as well. The coating of urea with bioactivated $\mathrm{ZnO}$ will also improve the $\mathrm{N}$ use efficiency. Recently, the application of urea coated with bioactivated $\mathrm{ZnO}$ to promote cereal growth, physiology, yield, and biofortification was reported by Nazir et al. [14] and Hussain et al. [16, 17]. Therefore, the effects of various formulation of urea coated with bioaugmented $\mathrm{ZnO}$ on wheat growth, yield, and $\mathrm{Zn}$ biofortification were investigated in a pot experiment under wirehouse conditions in this study. The wheat crop was selected being the staple food crop of Pakistan which contributes about $1.6 \%$ in GDP [18]. Hence, biofortifying the wheat with bioavailable $\mathrm{Zn}$ would help not only in combating the $\mathrm{Zn}$ deficiency in humans but also it will improve the Zn use efficiency.

\section{Materials and Methods}

Collection of bacterial strain: Preselected $\mathrm{Zn}$ solubilizing plant growth-promoting rhizobacterial strain Bacillus sp. AZ6 (accession number KT221633) [10] was collected from Environmental Sciences Laboratory, Institute of Soil and Environmental Sciences (ISES), University of Agriculture Faisalabad (UAF), Pakistan. Fresh inoculum of Bacillus sp. AZ6 was prepared by growing in Bunt and Rivera basal broth [19] in an orbital shaking incubator at $28 \pm 1^{\circ} \mathrm{C}$ and $100 \mathrm{rpm}$ for $72 \mathrm{~h}$. The inoculum of 0.5 optical density at $535 \mathrm{~nm}\left(\mathrm{OD}_{535}\right)$ was maintained to obtained $10^{8}-10^{9}$ colony forming units (CFU) $\mathrm{mL}^{-1}$.

Formulation of urea coated with bioaugmented $\mathrm{Zn}$ (BAZ): Different formulations of urea coated with bioaugmented $\mathrm{Zn}$ (BAZ) were prepared using the method reported by Nazir et al. [14]. For the preparation of urea coated with $\mathrm{BAZ}, \mathrm{ZnO}$ powder was passed 
through 300-400 mm mesh size sieve and augmented with Bacillus sp. AZ6 $\left(0.5\right.$ at $\left.\mathrm{OD}_{535}\right)$ in 40:60 (w/v) ratios (ZnO: Bacillus sp. AZ6) and incubated at $30 \pm 1^{\circ} \mathrm{C}$ for $72 \mathrm{~h}$. Orange peel waste was used as organic material, which was collected locally and ground into a powder after drying in an oven at $80{ }^{\circ} \mathrm{C}$. The fine powder of organic material was augmented with Bacillus sp. AZ6 $\left(0.5\right.$ at $\left.\mathrm{OD}_{535}\right)$ and incubated at $30 \pm 1^{\circ} \mathrm{C}$ for $72 \mathrm{~h}$. After incubation, bioaugmented organic material was thoroughly mixed with $\mathrm{ZnO}$ powder having 300-400 mesh size in 40:60 ratios ( $\mathrm{ZnO}$ : bioaugmented organic material). Three levels $(0.5,1.0$, and $1.5 \%)$ of $\mathrm{ZnO}$, $\mathrm{BAZ}$, and $\mathrm{BAZ}+$ organic material were coated on urea and incubated at $30 \pm 1^{\circ} \mathrm{C}$ for 72 .

Experimental description: The pot experiment was conducted in the wirehouse of the ISES, UAF, Pakistan, to assess the comparative effectiveness of various urea coated with $\mathrm{ZnO}, \mathrm{BAZ}$, and $\mathrm{BAZ}+$ organic material to enhance the wheat growth, yield, and $\mathrm{Zn}$ biofortification. Pots were filled with $12 \mathrm{~kg}$ of air-dried and sieved (2 mm mesh size) soil. Physicochemical properties of soil recorded were as sandy clay loam texture with $51.2 \%$ sand, $29.6 \%$ silt and $19.2 \%$ clay, $1.41 \mathrm{dS} \mathrm{m}^{-1}$ electrical conductivity (EC), $7.9 \mathrm{pH}, 0.68 \%$ OM, $0.06 \%$ total $\mathrm{N}, 8.79 \mathrm{mg} \mathrm{kg}^{-1}$ available P, $84 \mathrm{mg} \mathrm{kg}^{-1}$ extractable $\mathrm{K}$ and $0.65 \mathrm{mg} \mathrm{kg}^{-1}$ available $\mathrm{Zn}$ evaluated through following standard methods of Richards [20], Moodie et al. [21], Jackson [22], Watanabe and Olsen [23], and Soltanpour and Workman [24]. A set of twelve treatments including $\mathrm{T}_{0}=$ absolute control, $\mathrm{T}_{1}=\mathrm{ZnSO}_{4}$, $\mathrm{T}_{2}=$ Bacillus sp. AZ6, $\mathrm{T}_{3}=$ urea coated with $0.5 \% \mathrm{ZnO}$ $(\mathrm{U}-\mathrm{Zn} 1), \mathrm{T}_{4}=$ urea coated with $1.0 \% \mathrm{ZnO}(\mathrm{U}-\mathrm{Zn} 2)$, $\mathrm{T}_{5}=$ urea coated with $1.5 \% \mathrm{ZnO}(\mathrm{U}-\mathrm{Zn} 3), \mathrm{T}_{6}=$ urea coated with $0.5 \%$ BAZ (U-Bio-Zn1), $\mathrm{T}_{7}=$ urea coated with $1.0 \%$ BAZ (U-Bio-Zn2), $\mathrm{T}_{8}=$ urea coated with $1.5 \%$ BAZ (U-Bio-Zn3), $\mathrm{T}_{9}=$ urea coated with $0.5 \%$ $\mathrm{BAZ}+$ organic material (U-Bio-OM-Zn1), $\mathrm{T}_{10}=$ urea coated with $1.0 \%$ BAZ+organic material (U-Bio-OM$\mathrm{Zn} 2$ ), and $\mathrm{T}_{11}=$ urea coated with $1.5 \% \mathrm{BAZ}+$ organic material (U-Bio-OM-Zn3) were applied at the time of sowing. The wheat cultivar Faisalabad-2008 was sown and pots were arranged in a completely randomized design (CRD) in triplicate. The recommended dose of NPK $\left(160,110\right.$, and $\left.90 \mathrm{~kg} \mathrm{ha}^{-1}\right)$ for the wheat crop was applied using urea, diammonium phosphate (DAP) and sulfate of potash (SOP). $\mathrm{P}$ and $\mathrm{K}$ doses were applied at the time of sowing while two out of three split doses of $\mathrm{N}$, were applied after 30 and 60 days of germination. $\mathrm{Zn}$ was applied at the rate of $5 \mathrm{~kg} \mathrm{ha}^{-1}$ at sowing time. Tap water of good quality was used to irrigate the pots. At maturity, plants were harvested and data regarding growth, yield, and quality parameters were recorded. The growth parameters viz. plant height was taken with the help of measuring rod while spike weight per pot was taken through analytical balance.

Chemical analysis for determination of $\mathrm{Zn}$ concentration: The shoot and grain samples of wheat were oven-dried at $67^{\circ} \mathrm{C}$ up to constant weight. These samples were wet digested following the method of
Jones and Case [25]. The digested filtrate was read by the atomic absorption spectrophotometer (PerkinElmer, AAnalyst 100, Waltham, USA) to determine Zn concentration in the shoot and grains.

Determination of phytic acid in grains: The phytic acid concentration in wheat grains was determined by the colorimetric method described by Gao et al. [26]. The $0.5 \mathrm{~g}$ of wheat flour was mixed with $2.4 \%$ of hydrochloric acid $(\mathrm{HCl})$ and incubated at room temperature with shaking for $24 \mathrm{~h}$. On the next day, contents were centrifuged at $10000 \mathrm{rpm}$ for $10 \mathrm{~min}$ and the supernatant was transferred to another centrifuge tube containing $1.0 \mathrm{~g} \mathrm{NaCl}$. After vigorous shaking, $1 \mathrm{~mL}$ of clear supernatant was diluted to $25 \mathrm{~mL}$ with distilled water. After that, $3 \mathrm{~mL}$ of diluted sample mixed with $1 \mathrm{~mL}$ of Wade reagent (composed of $0.03 \% \mathrm{FeCl}_{3} 6 \mathrm{H}_{2} \mathrm{O}+0.3 \%$ sulfosalicylic acid) and spectrophotometer measurement was performed at $500 \mathrm{~nm}$.

Statistical Analysis: The data of observed attributes were collected and subjected to analysis of variance (ANOVA) by using computer software Statistix v. 8.1 (Analytical Software, USA). The treatment means were compared using the least significant difference (LSD) test at a $5 \%$ probability [27]. The significance of treatment means was presented by showing standard error and alphabetical lettering. The treatment means carrying the same letters were considered statistically non-significant $(p \leq 0.05)$.

\section{Results}

Plant height and number of tillers: The application of urea coated with BAZ and organic materials significantly $(p \leq 0.05)$ increased the plant height, number of tillers, and length of the flag leaf in wheat compared with control (Table 1). The maximum increase (18.6\%) in plant height was observed in plants under treatments U-Bio-OM-Zn3 and U-Bio-Zn3, which were statistically similar to treatments U-Zn3, U-Bio-Zn2, and U-BioOM-Zn2. Likewise, the maximum number of tillers per plant were observed with the application U-Bio-Zn3 and Bacillus sp. AZ6 alone, which were $57.4 \%$ higher than absolute control. These treatments were non-significant in comparison to $\mathrm{ZnSO}_{4}$ and U-Bio-Zn2; however, were highly significant compared with absolute control.

Yield contributing attributes: The impacts of urea coated with BAZ and organic materials on yield contributing attributes of wheat are reported in Table 1. The treatments of coated urea exhibited non-significant effects on spike weight per pot and grain yield; however, these attributes in all the treatments were significantly higher as compared to absolute control. The treatments $\mathrm{ZnSO}_{4}$, U-Zn3, U-Bio-Zn3, U-Bio-OM-Zn2, and U-BioOM-Zn3 performed batter than rest of the treatments showing the higher spike weight per pot and grain yield; nevertheless, these were statistically similar to each other. The application $\mathrm{ZnSO}_{4}$ resulted in the highest 
Table 1. Plant height, number of tillers, spike weight, and grain yield per plant of wheat plants grown with various bioaugmented zinccoated urea treatments.

\begin{tabular}{|c|c|c|c|c|}
\hline Treatments & $\begin{array}{c}\text { Plant height } \\
(\mathrm{cm})\end{array}$ & $\begin{array}{c}\text { Number of tillers } \\
\text { plant }\end{array}$ & $\begin{array}{c}\text { Spike weight } \\
\text { pot }^{-1}(\mathrm{~g})\end{array}$ & $\begin{array}{c}\text { Grain yield } \\
\text { pot }^{-1}(\mathrm{~g})\end{array}$ \\
\hline Absolute control & $91 \pm 1.6 \mathrm{de}$ & $4.7 \pm 0.1 \mathrm{de}$ & $38.7 \pm 0.7 \mathrm{~h}$ & $7.57 \mathrm{e}$ \\
\hline ZnSO $_{4}$ & $101 \pm 1.4 \mathrm{c}$ & $6.7 \pm 0.2 \mathrm{ab}$ & $62.0 \pm 0.6 \mathrm{a}$ & $8.53 \mathrm{~d}$ \\
\hline Bacillus sp. AZ6 & $85 \pm 1.8 \mathrm{f}$ & $7.4 \pm 0.5 \mathrm{a}$ & $42.0 \pm 1.7 \mathrm{~g}$ & $8.52 \mathrm{~d}$ \\
\hline U-Zn1 & $90 \pm 1.9 \mathrm{e}$ & $4.4 \pm 0.3 \mathrm{ef}$ & $46.0 \pm 1.7 \mathrm{ef}$ & $9.25 \mathrm{c}$ \\
\hline U-Zn2 & $107 \pm 1.2 \mathrm{~b}$ & $4.7 \pm 0.2 \mathrm{de}$ & $50.0 \pm 2.9 \mathrm{~cd}$ & $10.25 \mathrm{~b}$ \\
\hline U-Zn3 & $108 \pm 0.3 \mathrm{ab}$ & $5.4 \pm 0.2 \mathrm{~cd}$ & $51.4 \pm 0.6 \mathrm{c}$ & $9.25 \mathrm{c}$ \\
\hline U-Bio-Zn1 & $93 \pm 0.2 \mathrm{~d}$ & $4.7 \pm 0.2 \mathrm{de}$ & $47.7 \pm 0.6 \mathrm{de}$ & $10.42 \mathrm{~b}$ \\
\hline U-Bio-Zn2 & $108 \pm 1.8 \mathrm{ab}$ & $6.7 \pm 0.2 \mathrm{ab}$ & $52.1 \pm 1.2 \mathrm{c}$ & $12.43 \mathrm{a}$ \\
\hline U-Bio-Zn3 & $109 \pm 0.2 \mathrm{a}$ & $7.4 \pm 0.3 \mathrm{a}$ & $56.3 \pm 1.8 \mathrm{~b}$ & $8.17 \mathrm{~d}$ \\
\hline U-Bio-OM-Zn1 & $90 \pm 0.2 \mathrm{e}$ & $4.4 \pm 0.3 \mathrm{ef}$ & $44.7 \pm 0.2 \mathrm{fg}$ & $9.16 \mathrm{c}$ \\
\hline U-Bio-OM-Zn2 & $107 \pm 0.2 \mathrm{ab}$ & $4.7 \pm 0.2 \mathrm{de}$ & $47.1 \pm 1.2 \mathrm{ef}$ & $10.58 \mathrm{~b}$ \\
\hline U-Bio-OM-Zn3 & $109 \pm 0.5 \mathrm{a}$ & $5.4 \pm 0.1 \mathrm{~cd}$ & $51.0 \pm 2.4 \mathrm{c}$ & 1.6752 \\
\hline LSD $(p \leq 0.05)$ & 1.2697 & 0.7944 & 2.4645 & \\
\hline
\end{tabular}

Data were collected from three plants per pots and values are means of three replicates.

increase in spike weight per pot and grain yield $(60.2$ and $45 \%$, respectively), followed by the U-Bio-Zn3 application $(45.5 \%$ and $64 \%$, respectively), as compared to absolute control. The lowest values of spike weight and grain yield were observed under absolute control treatment.
Concentrations of $\mathrm{Zn}$ in shoot and grains: The application of urea coated with BAZ, as well as BAZ with organic material promoted the accumulation of $\mathrm{Zn}$ contents shoot and grains of wheat significantly (Table 2). The highest increase in shoot $\mathrm{Zn}$ concentrations was observed by the application of

Table 2. Zinc concentration in the shoot, and grains, phytate contents in grains, and grain phytate: zinc ratios of wheat plants grown with various bioaugmented zinc-coated urea treatments.

\begin{tabular}{|c|c|c|c|c|}
\hline \multirow{2}{*}{ Treatments } & \multicolumn{2}{|c|}{ Zinc concentration $\left(\mu \mathrm{g} \mathrm{g}^{-1}\right)$} & Grains phytate contents \\
\cline { 2 - 4 } & Shoot & Grains & $\begin{array}{c}\text { Grain phytate: zinc } \\
\text { ratios }\end{array}$ \\
\hline Absolute control & $9.6 \pm 0.2 \mathrm{f}$ & $17.5 \pm 0.3 \mathrm{k}$ & $1099.0 \pm 15 \mathrm{a}$ & $62.8 \pm 1.3 \mathrm{a}$ \\
\hline ZnSO $_{4}$ & $15.6 \pm 0.6 \mathrm{~b}$ & $36.5 \pm 3.4 \mathrm{c}$ & $433.6 \pm 19 \mathrm{f}$ & $11.8 \pm 0.2 \mathrm{~h}$ \\
\hline Bacillus sp. AZ6 & $12.9 \pm 0.2 \mathrm{~d}$ & $20.5 \pm 0.3 \mathrm{e}$ & $950.1 \pm 19 \mathrm{~d}$ & $46.3 \pm 0.7 \mathrm{~b}$ \\
\hline U-Zn1 & $13.4 \pm 0.3 \mathrm{~d}$ & $28.2 \pm 1.9 \mathrm{e}$ & $1090.0 \pm 14 \mathrm{a}$ & $38.7 \pm 0.5 \mathrm{~d}$ \\
\hline U-Zn2 & $13.7 \pm 0.6 \mathrm{c}$ & $38.5 \pm 1.5 \mathrm{~b}$ & $1009.3 \pm 2 \mathrm{bc}$ & $26.2 \pm 0.7 \mathrm{e}$ \\
\hline U-Zn3 & $16.5 \pm 0.3 \mathrm{~b}$ & $18.5 \pm 0.3 \mathrm{f}$ & $450.3 \pm 29 \mathrm{fg}$ & $24.3 \pm 1.0 \mathrm{i}$ \\
\hline U-Bio-Zn1 & $13.0 \pm 0.6 \mathrm{e}$ & $38.6 \pm 0.2 \mathrm{~b}$ & $1068.5 \pm 5 \mathrm{~b}$ & $27.7 \pm 0.2 \mathrm{e}$ \\
\hline U-Bio-Zn2 & $14.5 \pm 0.3 \mathrm{c}$ & $42.5 \pm 0.3 \mathrm{ab}$ & $740.7 \pm 15 \mathrm{e}$ & $17.4 \pm 0.7 \mathrm{~g}$ \\
\hline U-Bio-Zn3 & $17.6 \pm 0.2 \mathrm{a}$ & $42.7 \pm 0.2 \mathrm{a}$ & $330.7 \pm 17 \mathrm{~g}$ & $7.8 \pm 0.4 \mathrm{j}$ \\
\hline U-Bio-OM-Zn1 & $12.0 \pm 0.5 \mathrm{e}$ & $20.5 \pm 0.3 \mathrm{e}$ & $965.4 \pm 17 \mathrm{~cd}$ & $47.3 \pm 1.2 \mathrm{c}$ \\
\hline U-Bio-OM-Zn2 & $13.4 \pm 0.3 \mathrm{~d}$ & $35.5 \pm 1.6 \mathrm{c}$ & $768.7 \pm 6 \mathrm{e}$ & $21.6 \pm 0.7 \mathrm{f}$ \\
\hline U-Bio-OM-Zn3 & $15.5 \pm 0.8 \mathrm{c}$ & $38.5 \pm 1.6 \mathrm{~b}$ & $430.7 \pm 5 \mathrm{f}$ & $11.2 \pm 0.7 \mathrm{i}$ \\
\hline LSD $(p \leq 0.05)$ & 0.5692 & 1.1190 & 73.723 & 1.0128 \\
\hline
\end{tabular}

Data were collected from three plants per pots and values are means of three replicates. 
U-Bio-Zn3, followed by the application of U-Zn3 and $\mathrm{ZnSO}_{4}$, which were $83.3 \%, 71.9 \%$ and $62.5 \%$ more, respectively, as compared to absolute control. Overall, the $\mathrm{Zn}$ concentration in grains was more than that in the shoots of the wheat plants. The highest concentration of $\mathrm{Zn}$ was exhibited with the application of U-Bio-Zn3, followed by the application of U-Bio-Zn2, which were $144.0 \%$ and $142.9 \%$ higher, respectively, as compared to absolute control. These treatments were non-significant to each other but significantly higher than absolute control.

The phytic acid concentration in grains: The highest grain phytic acid concentration and phytate:Zn molar ratios were observed in control treatment (Table 2). It was observed that the application of urea coated with $\mathrm{BAZ}$, as well as BAZ + organic material treatments, resulted in a reduction in phytic acid accumulation in grains and phytate: $\mathrm{Zn}$ molar ratios. The highest reduction $(69.9 \%)$ in phytate concentration was observed under the treatment of U-Bio-Zn3, as compared to absolute control. However, the differences among other treatments were non-significant. Similarly, the maximum reduction in grain phytate: $\mathrm{Zn}$ molar ratios was observed in treatment U-Bio-Zn3 as compared to absolute control.

\section{Discussion}

Currently, the application of $\mathrm{ZnSO}_{4}$ is being practiced to overcome the $\mathrm{Zn}$ deficiency in soils; however, its use is limited among the farmer's community due to higher costs and low $\mathrm{Zn}$ use efficiency [28]. Contrary, ZnO is a cheaper source of $\mathrm{Zn}$ and contains about $80 \%$ of $\mathrm{Zn}$; however, being insoluble, the direct use of $\mathrm{ZnO}$ in calcareous soils is inefficient. This insoluble $\mathrm{Zn}$ can be solubilized by various $\mathrm{Zn}$ solubilizing bacterial (ZSB) strains as reported by Fasim et al. [29], Sharma et al. [30], Ramesh et al. [31], Hussain et al. [10], Khande et al. [10], and Mumtaz et al. [11]. The available Zn concentration due to solubilization activity of ZSB strains could be termed as bioactivated $\mathrm{Zn}$ which had been previously reported by Nazir et al. [14] and Hussain et al. [16, 17]. This bioactivated $\mathrm{Zn}$ fertilizer has higher $\mathrm{Zn}$ use efficiency than the conventional $\mathrm{ZnSO}_{4}$ fertilizers [14].

In the present study, various treatments of urea coated with BAZ, as well as BAZ along with organic material were applied to evaluate their effects on wheat growth, yield, and Zn biofortification. Results revealed that the application of urea coated with BAZ showed a significant increase in wheat growth, yield, and $\mathrm{Zn}$ biofortification as compared to the sole application of $\mathrm{ZnSO}_{4}$, and Bacillus sp. AZ6. The efficiency of applied treatment was in the order of U-Bio-Zn3>U-Bio-OM$\mathrm{Zn} 3>\mathrm{ZnSO}_{4}>\mathrm{U}-\mathrm{Bio}-\mathrm{Zn} 2>\mathrm{U}-\mathrm{Bio}-\mathrm{OM}-\mathrm{Zn} 2>\mathrm{U}-\mathrm{Zn} 3>$ U-Bio-Zn1 $>$ U-Bio-OM-Zn1 $>$ U-Zn2 $>$ U-Zn $1>\mathrm{ZnO}>$ absolute control. The increase in these wheat growths and yield attributes due to the application of urea coated with BAZ with and without organic materials could be attributed to an increase in $\mathrm{N}$ and $\mathrm{Zn}$ use efficiency. The increased $\mathrm{N}$ use efficiency may have reduced $\mathrm{N}$ losses through denitrification, volatilization, surface runoff, and leaching $[32,33]$. The increased $\mathrm{N}$ use efficiency subsequently resulted in increased yield and reduction in the cost of production by supplying a sufficient amount of $N$ [34]. Babar et al. [35] reported that the application of urea coated with $\mathrm{Zn}$ and copper showed a reduction in ammonia volatilization and maximized the N-uptake. Likewise, Shivay et al. [36] applied urea coated with boron, sulfur, and $\mathrm{Zn}$ and reported an improvement in nutrient use efficiencies and harvest index. These urea-coated fertilizers showed an increase in grain yield of up to $13 \%, 25 \%$, and $17.9 \%$ as compared to prilled urea. These findings may suggest that the application of urea coated with BAZ could be a better source of nutrients supply for plant growth and development.

In the present study, the application of $0.5 \%$, $1.0 \%$, and $1.5 \%$ of $\mathrm{ZnO}$ with urea showed an increase in wheat growth, yield, and $\mathrm{Zn}$ biofortification as compared to control. However, the sole as well as the integrated application of $1.5 \%$ of $\mathrm{ZnO}$ with urea, Bacillus sp. AZ6 and organic material showed a higher increase in wheat growth, yield, Zn biofortification. The $\mathrm{ZnO}$ bioaugmented with Bacillus sp. AZ6 might have solubilized the insoluble $\mathrm{Zn}$ contents as this strain is reported to have $\mathrm{Zn}$ solubilizing activity [10]. Mumtaz et al. [12] reported solubilization of $\mathrm{ZnO}$ up to $0.2 \%$ with Bacillus sp. ZM20 and Bacillus cereus. The synthetic mock mixture of these metabolites has also shown in vitro solubilization of $\mathrm{ZnO}$ [12]. Therefore, the bioaugmentation with Bacillus sp. AZ6 enhanced the wheat growth, yield, and $\mathrm{Zn}$ biofortification over the sole application of $\mathrm{ZnO}$ in this study. However, this increase was lower as compared to urea coated with BAZ formulations. The success in the bioactivation of $\mathrm{Zn}$ by Bacillus sp. inoculation depends on its ability to colonize, survive, and solubilize $\mathrm{Zn}$ in the rhizosphere under natural conditions.

Organic matter is a source of nutrients for inoculated bacterial strain [37], hence, the presence of supplementary organic material has resulted in the higher bacterial population in urea coated with BAZ. The coating of urea with such bioactivated $\mathrm{Zn}$ could be beneficial in providing nutrients to the plant and improves plant growth and development as previously reported by Nazir et al. [14] and Hussain et al. [16, 17]. The application of urea coated with BAZ might have direct contact with roots, consequently increasing $\mathrm{Zn}$ and $\mathrm{N}$ availability due to less adsorption on clay complexes and leaching below the root zone [28]. An increase in wheat growth and yield could also be due to improved root growth, which increased the acquisition of water and nutrients from the soil, which resulted in enhanced plant growth and yield. In the current study, the application of urea coated with BAZ significantly improved the accumulation of $\mathrm{Zn}$ concentration 
in the root, shoot, and grains of wheat, suggesting that the higher capability of bioaugmented Bacillus sp. AZ6 for bioactivation of $\mathrm{Zn}$ from $\mathrm{ZnO}$. The urea coated with bioactivated $\mathrm{ZnO}$ improved the bioavailability of $\mathrm{Zn}$ that might have decreased soil $\mathrm{pH}$ and chelating $\mathrm{Zn}$. These treatments might also improve the plant's ability to uptake higher $\mathrm{Zn}$ contents because of available $\mathrm{Zn}$ contents in the soil for longer periods. Moreover, efficient translocation to shoots and remobilization of $\mathrm{Zn}$ [38] might be the reasons for improved $\mathrm{Zn}$ loading in grains (biofortification). Previously, an increase in grains $\mathrm{Zn}$ contents was also reported when the crop was inoculated with ZSB genera of Pseudomonas and Bacillus [13, 39, 40].

The bioavailable fraction of wheat grains is very important for human consumption [4]. Commonly, wheat grains contain lower bioavailable $\mathrm{Zn}$ concentrations due to the presence of an anti-nutrition factor called phytic acid [4, 41]. Phytic acid is the major storage form of $\mathrm{P}$ in wheat and other cereals grains. It can chelate $\mathrm{Zn}$ and limit the bioavailability of $\mathrm{Zn}$ for humans due to a lack of phytase in their digestive tract [42]. Application of synthetic Zn sources and/or ZSB had been reported to increase the $\mathrm{Zn}$ contents in grains and reduction of phytic acid concentration in grains [43, 44]. In the current study, the application of urea coated with BAZ resulted in reduced phytic acid and phytate:Zn molar ratios that might be due to increased $\mathrm{Zn}$ availability in soil and grown dilution effect for lower phytate contents compared with control treatment. This lower phytate:Zn ratios are helpful for human consumption of such $\mathrm{Zn}$ enrich grains and improve feed efficiency [4]. Rehman et al. [45] reported that the application of $\mathrm{Zn}$ augmented with Pseudomonas sp. MN12 improved Zn contents in grains and showed a reduction in phytic acid concentration. Thus, the current study revealed that the application of urea coated with BAZ could be a novel strategy to improve wheat biofortification by reducing phytic acid concentration in grains that can potentially help in alleviating malnutrition problems in the human beings of developing countries.

The overall increased $\mathrm{Zn}$ and $\mathrm{N}$ use efficiency by application of bioaugmented $\mathrm{Zn}$ coated urea is a promising technique in improving not only the growth and yield of the wheat crop but the $\mathrm{Zn}$ biofortification. Moreover, the availability of coated urea with $\mathrm{Zn}$ can increase the $\mathrm{Zn}$ application in soils as most of the farmers apply urea fertilizer alone, without considering any other nutrient. This product will not only reduce the cost of $\mathrm{N}$ and $\mathrm{Zn}$ fertilizers having high use efficiency but also will reduce the environmental concerns of $\mathrm{N}$ emissions to the environment. However, this aspect warrants further investigations.

\section{Conclusions}

The application of urea coated with $1.5 \%$ of $\mathrm{ZnO}$ and BAZ with and without organic material could be a possible potential solution to improve wheat productivity and $\mathrm{Zn}$ biofortification. Such potential treatments may enhance the $\mathrm{Zn}$ concentrations in wheat grain through reducing phytic acid as well as phytate: $\mathrm{Zn}$ molar ratios in grains. The farmers of poor communities can get maximum benefit by using urea coated with bioactivated $\mathrm{ZnO}$ and can improve $\mathrm{Zn}$ intake through consuming such $\mathrm{Zn}$ enrich wheat grains to fulfills the human's requirements of $\mathrm{Zn}$.

\section{Conflict of Interest}

The authors declare no conflict of interest.

\section{References}

1. Sustainable Development Goals. End hunger, achieve food security and improved nutrition and promote sustainable agriculture. Goal 2: Zero Hunger. Retrieved from http:// www.fao.org/sustainable-development-goals/goals/goal-2/ en/ 2019.

2. FAO, IFAD, UNICEF, WFP, \& WHO. The State of Food Security and Nutrition in the World. Safeguarding against Economic Slowdowns and Downturns Food and Agriculture Organization of the UN, Rome. 00148 Rome, Italy. Retrieved from https://www.wfp.org/ publications/2019-state-food-security-and-nutrition-worldsofi-safeguarding-against-economic 2019.

3. HAMBIDGE M. Human Zinc Deficiency. The Journal of Nutrition, 130 (5), 1344, 2000.

4. HUSSAIN S., MAQSOOD M.A., RENGEL Z., AZIZ T. Biofortification and estimated human bioavailability of zinc in wheat grains as influenced by methods of zinc application. Plant and Soil, 361 (1-2), 279, 2012.

5. MAYER J.E., PFEIFFER W.H., BEYER P. Biofortified crops to alleviate micronutrient malnutrition This review comes from a themed issue on Plant Biotechnology Edited by. Current Opinion in Plant Biology, 11, 1, 2008.

6. PRASAD R. Zinc biofortification of food grains in relation to food security and alleviation of zinc malnutrition. Current Science, 98 (10), 1300, 2010.

7. PFEIFFER W.H., MCCLAFFERTY B. HarvestPlus: Breeding Crops for Better Nutrition HarvestPlus Challenge Program of the CGIAR Research Program on Agriculture for Nutrition and Health (A4NH). View project Biofortified Crops for Improved Human Nutrition. Crop Science, 47 (S3), 88S, 2007.

8. ALLOWAY B. Soil factors associated with zinc deficiency in crops and humans. Environmental Geochemistry and Health, 31 (5), 537, 2009.

9. BUNQUIN M., TANDY S., BEEBOUT S., SCHULIN R. Influence of Soil Properties on Zinc Solubility Dynamics Under Different Redox Conditions in Non-Calcareous Soils. Pedosphere, 27 (1), 96, 2017.

10. HUSSAIN A., ARSHAD M., ZAHIR Z.A., ASGHAR M. Prospects of zinc solubilizing bacteria for enhancing growth of maize Development of Novel Rhizobial Inoculants for Inducing Drought Tolerance in Cereals View project m.phil View project. Pakistan Journal of Agricultural Sciences, 52, 915, 2015.

11. MUMTAZ M.Z., AHMAD M., JAMIL M., HUSSAIN T. Zinc solubilizing Bacillus spp. potential candidates for 
biofortification in maize. Microbiological Research, 202, 51, 2017.

12. MUMTAZ M., BARRY K., BAKER A., NICHOLS D., AHMAD M., ZAHIR Z., BRITZ M. Production of lactic and acetic acids by Bacillus sp. ZM20 and Bacillus cereus following exposure to zinc oxide: A possible mechanism for Zn solubilization. Rhizosphere, 12, 100170, 2019.

13. MUMTAZ M.Z., AHMAD M., JAMIL M., ASAD S.A., HAFEEZ F. Bacillus strains as potential alternate for zinc biofortification of maize grains. International Journal of Agriculture and Biology, 20 (8), 2018.

14. NAZIR Q., ARSHAD M.G., AZIZ T., SHAHID M. Influence of Zinc Impregnated Urea on Growth, Yield and Grain Zinc in Rice (Oryza sativa). International Journal of Agriculture and Biology, 18, 1195, 2016.

15. HAVLIN J., TISDALE S., NELSON W., BEATON J. Soil fertility and fertilizers: An introduction to nutrient management $\left(7^{\text {th }}\right.$ ed.). Upper Saddle River, New Jersey: Pearson Education, Inc. 2005.

16. HUSSAIN A., ZAHIR Z.A., ASGHAR H.N., IMRAN M., AHMAD M., HUSSAIN S. Integrating the potential of Bacillus SP. AZ6 and organic waste for zinc oxide bioactivation to improve growth, yield and zinc content of maize grains. Pakistan Journal of Agriculture Science, $\mathbf{5 7}$ (1), 123, 2020.

17. HUSSAIN A., ZAHIR Z.A., DITTA A., TAHIR M.U., AHMAD M., ZAHID MUMTAZ M., HUSSAIN S. Production and Implication of Bio-Activated Organic Fertilizer Enriched with Zinc-Solubilizing Bacteria to Boost up Maize (Zea mays L.) Production and Biofortification under Two Cropping Seasons. Agronomy, 10 (1), 39, 2019.

18. Pakistan Economic Survey. Chapter 2: Agriculture. Government of Pakistan. Islamabad, Pakistan. Retrieved from http://finance.gov.pk/survey/chapters_19/Economic_ Survey_2018_19.pdf 2018.

19. BUNT J.S., ROVIRA A.D. Microbiological studies of some subantarctic soils. Journal of Soil Science, 6 (1), 119, 1955.

20. RICHARDS L.A. Diagnosis and Improvement of Saline and Alkali Soils. Handbook No. 60, United States Salinity Laboratory Staff. California, USA. 1954.

21. MOODIE C., SMITH H., MCCREERY R. Laboratory manual for soil fertility. Washington USA: Department of Agronomy, State College of Washington Pullman. 1959.

22. JACKSON M. Soil Chemical Analysis. Prentice Hall, Inc. Englwood Cliff, New York, USA. Journal of Plan Nutrition and Soil Science, 85 (3), 251, 1962.

23. WATANABE F., OLSEN S. Test of an ascorbic acid method for determining phosphorus in water and $\mathrm{NaHCO}_{3}$ extracts from soil 1. Soil Science Society of America, 29 (6), 677, 1965

24. SOLTANPOUR P.N., WORKMAN S. Modification of the $\mathrm{NH}_{4} \mathrm{HCO}_{3}$-DTPA soil test to omit carbon black. Communications in Soil Science and Plant Analysis, 10 (11), 1411, 1979.

25. JONES J., CASE V. Sampling, handling and analyzing plant tissue samples. In R. L. Westerman (Ed.), Soil Testing and Plant Analysis ( $3^{\text {rd }}$ ed., pp. 389-447). Madison, Wisconsin, USA: Soil Science Society of America, Book Series. 1990

26. GAO L., ZHUANG J., NIE L., ZHANG J., ZHANG Y., GU N., YAN X. Intrinsic peroxidase-like activity of ferromagnetic nanoparticles. Nature Nanotechnology, 2, $577,2007$.
27. STEEL R., TORRIE J., DICKY D. Principles and Procedures of Statistics, A Biometrical Approach ( $3^{\text {rd }}$ ed.). New York: McGraw Hill, Inc. Book Co. 1997.

28. SHIVAY Y.S., KUMAR D., PRASAD R. Effect of zincenriched urea on productivity, zinc uptake and efficiency of an aromatic rice-wheat cropping system. Nutrient Cycling in Agroecosystems, 81 (3), 229, 2008.

29. FASIM F., AHMED N., PARSONS R., GADD G.M. Solubilization of zinc salts by a bacterium isolated from the air environment of a tannery. FEMS Microbiology Letters, 213, 1, 2002.

30. SHARMA S., RAMESH A., JOSHI O. Characterization of zinc-solubilizing Bacillus isolates and their potential to influence zinc assimilation in soybean seeds. Journal of Microbiology and Biotechnology. 2012.

31. RAMESH A., SHARMA S.K., SHARMA M.P., PRAKASH JOSHI SOLIDARIDAD SOUTH O., EAST ASIA S., YADAV N., JOSHI O.P. Inoculation of zinc solubilizing Bacillus aryabhattai strains for improved growth, mobilization and biofortification of zinc in soybean and wheat cultivated in Vertisols of central India. Applied Soil Ecology, 73 (6), 87, 2014.

32. RAZA S., ZHOU J., AZIZ T., AFZAL M., AHMED M., JAVAID S., CHEN Z. Piling up reactive nitrogen and declining nitrogen use efficiency in Pakistan: a challenge not challenged (1961-2013). Environmental Research Letters, 13, 034012, 2018.

33. ASHRAF M.N., AZIZ T., MAQSOOD M.A., BILAL H.M., RAZA,S., ZIA M., WANG Y. Evaluating Organic Materials Coating on Urea as Potential Nitrification Inhibitors for Enhanced Nitrogen Recovery and Growth of Maize (Zea mays). International Journal of Agriculture and Biology, 22, 1102, 2019.

34. FAGERIA N., BALIGAR V. Enhancing nitrogen use efficiency in crop plants. Advances in Agronomy, 88, 97, 2005.

35. BABAR S.K., YUSOP M.K., BABAR S.A., KHOOHARO A.A. Consequences of $\mathrm{Cu}$ and $\mathrm{Zn}$ coated urea to minimize ammonia volatilization. Jurnal Teknologi, 78, 1, 2016.

36. SHIVAY Y.S., POONIYA V., PAL M., GHASAL P.C., BANA R., JAT S.L. Coated Urea Materials for Improving Yields, Profitability, and Nutrient Use Efficiencies of Aromatic Rice. Global Challenges, 3 (12), 1900013, 2019.

37. DITTA A., KHALID A. Bio-Organo-Phos: A Sustainable Approach for Managing Phosphorus Deficiency in Agricultural Soils. In Marcelo L. Larramendy \& Sonia Soloneski (Eds.), Organic Fertilizers: From Basic Concepts to Applied Outcomes (pp. 109-136). Rijeka, Kroatia: InTech. 2016.

38. ZHAO L., YUAN L., WANG Z., LEI T., YIN X. Phytoremediation of Zinc-Contaminated Soil and ZincBiofortification for Human Nutrition. In Yin X. \& Yuan L. (Eds.), Phytoremediation and Biofortification (pp. 33-57). Dordrecht: SpringerBriefs in Molecular Science. Springer, 2012.

39. BIARI A., GHOLAMI A., RAHMANI H. Growth promotion and enhanced nutrient uptake of maize (Zea mays L.) by application of plant growth promoting rhizobacteria in arid region of Iran. Journal of Biological Sciences, 8 (6), 1015, 2008.

40. GOTETI P.K., DANIEL L., EMMANUEL A., DESAI S., HASSAN M., SHAIK A. Prospective Zinc Solubilising Bacteria for Enhanced Nutrient Uptake and Growth Promotion in Maize (Zea mays L.). International Journal of Microbiology, 2013, 869697, 2013. 
41. PAHLAVAN-RAD M.R., PESSARAKLI M. Response of wheat plants to zinc, iron, and manganese applications and uptake and concentration of zinc, iron, and manganese in wheat grains. Communications in Soil Science and Plant Analysis, 40 (7-8), 1322, 2009.

42. GUPTA N., RAM H., KUMAR B. Mechanism of Zinc absorption in plants: uptake, transport, translocation and accumulation. Reviews in Environmental Science and Biotechnology. Springer Netherlands. 2016.

43. CAKMAK I. Enrichment of cereal grains with zinc: Agronomic or genetic biofortification? Plant and Soil, 302 (1-2), 1, 2008.
44. HAFEEZ F.Y., ABAID-ULLAH M., HASSAN M.N. Plant Growth-Promoting Rhizobacteria as Zinc Mobilizers: A Promising Approach for Cereals Biofortification. In Dinesh K. Maheshwar, M. Saraf, \& A. Aeron (Eds.), Bacteria in Agrobiology: Crop Productivity (pp. 217-235). Springer-Verlag Berlin Heidelberg. 2013.

45. REHMAN A., FAROOQ M., NAVEED M., OZTURK L., NAWAZ A. Pseudomonas-aided zinc application improves the productivity and biofortification of bread wheat. Crop and Pasture Science, 69 (7), 659, 2018. 